\title{
Classification of Anemia with Digital Images of Nails and Palms using the Naive Bayes Method
}

Klasifikasi Anemia dengan Citra Digital Kuku dan Telapak Tangan menggunakan Metode Naive Bayes

\author{
Nandha Juniaroesita Peksi' ${ }^{1}$, Bambang Yuwono², Mangaras Yanu Florestiyanto ${ }^{3}$ \\ 1,2,3 Informatika, Universitas Pembangunan Nasional Veteran Yogyakarta, Indonesia \\ 1'nandhajuniaa@gmail.com, ${ }^{2 *}$ bambangy@gmail.com, ${ }^{3}$ mangaras.yanu@upnyk.ac.id \\ *: Penulis korenspondensi (corresponding author)
}

\section{Informasi Artikel}

Received: 21 December 2020

Revised: 20 January 2021

Accepted: 13 February 2021

Published: 28 February 2021
Keywords:anemia; classification; naive bayes

Kata kunci: anemia; klasifikasi; naive bayes

\begin{abstract}
Purpose: Early detection of anemia based on nails and palms images by applying the Naive Bayes method, as well as to measure the level of accuracy in detecting anemia.

Design/methodology/approach: Using the Naive Bayes method. System development uses the waterfall method.

Findings/result: Based on the results of the tests that have been carried out, the resulting accuracy is $87.5 \%$ with varying light intensities and is $92.3 \%$ by using a light intensity of 5362 Lux.

Originality/value/state of the art: The difference between this study and previous research is in the image preprocessing method and classification method. In this study, the images of the nails and palms were converted to the $\mathrm{YCbCr}$ color space to be segmented and color features extracted. Then the color features will be classified using the Naive Bayes classification method. The output of this system is the result of the input image classification, whether normal or anemic.
\end{abstract}

\section{Abstrak}

Tujuan: Mendeteksi dini penyakit anemia berdasarkan citra kuku dan telapak tangan dengan menerapkan metode naive bayes, serta untuk mengukur tingkat akurasi dalam mendeteksi anemia.

Perancangan/metode/pendekatan: Menggunakan metode naive bayes. Pengembangan sistem menggunakan metode waterfall.

Hasil: Berdasarkan hasil pengujian yang telah dilakukan, dihasilkan akurasi sebesar $87,5 \%$ dengan intensitas cahaya 
yang bervariasi dan tingkat akurasi sebesar 92,3\% dengan menggunakan intensitas cahaya 5362 Lux.

Keaslian/ state of the art: Perbedaan penelitian ini dengan penelitian sebelumnya adalah pada bagian metode preprocessing citra dan metode klasifikasi. Pada penelitian ini citra kuku dan telapak tangan dikonversi ke ruang warna YCbCr untuk disegmentasi dan diekstraksi fitur warnanya. Kemudian fitur warna tersebut akan diklasifikasikan menggunakan metode klasifikasi naive bayes. Output dari sistem ini berupa hasil klasifikasi citra input termasuk normal atau anemia.

\section{Pendahuluan}

Anemia merupakan suatu keadaan dimana kadar hemoglobin dibawah normal. Hemoglobin adalah protein kaya zat besi yang memberikan warna merah pada darah. Protein ini membantu sel-sel darah merah membawa oksigen dari paru-paru ke seluruh tubuh. Sehingga apabila penyakit anemia ini dibiarkan secara berlarut-larut akan mengganggu fungsi organ-organ penting tubuh dan menimbulkan berbagai macam penyakit. Gejala yang terjadi pada penderita anemia adalah cepat lesu, lemah, letih, lelah, dan cepat lupa [1]. Prevalensi anemia di negara berkembang diperkirakan mencapai 43\%. Namun, kebanyakan orang tidak menyadari anemia yang dialaminya. Sedangkan apabila penderita mendapatkan penanganan yang terlambar maka akan terjadi dampak yang lebih serius.

Cara untuk mengetahui apakah seseorang mengalami anemia atau tidak, bisa dengan cara mengambil sampel darah kemudian dilakukan uji laboratorium. Namun, melalui cara ini penderita harus merasakan sakit pada saat pengambilan sampel darah dan menunggu beberapa hari sampai hasilnya keluar. Karena ketidakpraktisan tersebut mengakibatkan sebagian besar masyarakat malas untuk memeriksakan dirinya secara rutin.

Selain cara tersebut, ada cara lain yang lebih mudah dalam mendeteksi anemia yaitu dengan melihat bagian konjungtiva, jari tangan, telapak tangan, dan lidah. Penelitian tentang korelasi antara kemerahan konjungtiva, jari tangan, telapak tangan, dan lidah dengan kadar hemoglobin pernah dilakukan oleh [2], hasil dari penelitian tersebut menunjukkan bahwa kepucatan telapak tangan dan kuku merupakan parameter terbaik untuk mendeteksi anemia dengan tingkat sensitivitas $90 \%$. Sedangkan kepucatan konjungtiva memiliki sensitivitas $81 \%$ dan lidah 59\%. Penelitian lain [3], menghasilkan akurasi yang rendah yaitu $41,42 \%$ hingga $54,28 \%$. Kerendahan tingkat akurasi pada penelitian tersebut disebabkan karena pada kenyataannya penilaian seseorang terhadap warna berbeda-beda sehingga menghasilkan data yang subjektif.

Untuk menghilangkan kesubjektivan tersebut, perlu dilakukan penilaian warna dengan menggunakan pengolahan citra. Penilaian warna dilakukan dengan mencari nilai RGB pada citra yang mengandung objek yang diteliti. Namun, citra tersebut harus disegmentasi terlebih dahulu untuk menghilangkan latar belakangnya. Penelitian [4] melakukan segmentasi kuku dengan menggunakan ruang warna HSV. Hasil dari penelitian ini adalah lunula dan pelat kuku dapat disegmentasi dengan baik. penelitian lain yang menggunakan ruang warna HSV adalah [5], melakukan segmentasi citra kulit menghasilkan akurasi sebesar 87,86\% untuk satu orang dalam gambar dengan latar belakang putih dan 77,65\% di lapangan terbuka. Penelitian lain 
[6], [7] melakukan segmentasi wajah menggunakan ruang warna YCbCr. Menurut [6] pada ruang warna $\mathrm{YCbCr}$, warna dan tekstur kulit pada citra dapat digunakan untuk mengidentifikasi objek. Kemudian ruang warna $\mathrm{YCbCr}$ juga memberikan pendekatan komputasi yang sangat efisien dan akurat untuk deteksi kulit. Namun, menurut [7] segmentasi citra kulit menggunakan ruang warna $\mathrm{YCbCr}$ memiliki kelemahan yaitu sering melakukan kesalahan apabila terdapat wilayah yang memiliki warna serupa dengan warna kulit. Pada [8] membandingkan ruang warna $\mathrm{HSV}$ dengan $\mathrm{YCbCr}$ dan memberikan hasil bahwa ruang warna YCbCr lebih efektif dalam melakukan segmentasi dan deteksi kulit.

Setelah fitur warna didapatkan, maka selanjutnya dilakukan klasifikasi. Penelitian tentang klasifikasi anemia menggunakan citra konjungtiva pernah dilakukan oleh [9]. Pada penelitian tersebut menggunakan metode thresholding dan menghasilkan tingkat akurasi sebesar 78,9\%. Penelitian selanjutnya [10] dengan citra kuku menggunakan metode regresi linear berganda yang menghasilkan tingkat akurasi sebesar 97\%. Penelitian [11] dengan citra konjungtiva, menggunakan metode k-means menghasilkan tingkat akurasi sebesar $90 \%$ dan [12] dengan citra telapak tanganmenggunakan metode Local Binary Pattern (LBP) dan Particle Swarm Optimization (PSO) menghasilkan tingkat akurasi sebesar 98\%. Masalah yang ada pada penelitian sebelumnya adalah penggunaan metode thresholding yang memiliki kendala yaitu tingkat akurasi sistem bergantung pada kuantitas data latih yang digunakan, seperti yang dialami oleh [9]. Sehingga data yang dibutuhkan banyak untuk mencapai akurasi yang tinggi. Untuk menghindari hal tersebut dapat dilakukan dengan menambahkan metode klasifikasi yang hanya memerlukan sedikit data latih yaitu metode naive bayes [13].

Penelitian sebelumnya yang menggunakan metode naive bayes adalah [14] melakukan deteksi telapak tangan untuk membuat sistem keamanan menghasilkan tingkat akurasi sebesar 70\%. Penelitian [13] mendeteksi penyakit kulit menghasilkan akurasi sebesar 94,3\% untuk kasus jinak, 91,2\% untuk melanoma, dan 92,9\% untuk keratosis. Penelitian [15] mendeteksi penyakit kulit menghasilkan akurasi terbaik sebesar 94,44\%. Penelitian [16] mendeteksi penyakit paru-paru menghasilkan akurasi sebesar 90\%, dan penelitian [17] melakukan identifikasi wajah menghasilkan akurasi rata-rata sebesar 90,25\%. Selanjutnya penelitian [18] melakukan klasifikasi gerakan tangan, menghasilkan tingkat akurasi diatas $90 \%$.

Berdasarkan penelitian sebelumnya menjadikan dasar dilakukannya penelitian ini. Penelitian ini menerapkan metode naive bayes untuk mengklasifikasi anemia dengan menggunakan nilai rata-rata $\mathrm{R}, \mathrm{G}, \mathrm{B}$ dari citra digital kuku dan telapak tangan sebagai parameter yang akan dijadikan masukkan untuk metode klasifikasi naive bayes. Output dari penelitian ini berupa hasil klasifikasi dari citra yang diinputkan apakah termasuk kedalam kelas normal atau anemia.

\section{Metode/Perancangan}

Langkah-langkah untuk melakukan penelitian ini dapat dilihat pada Gambar 1. 


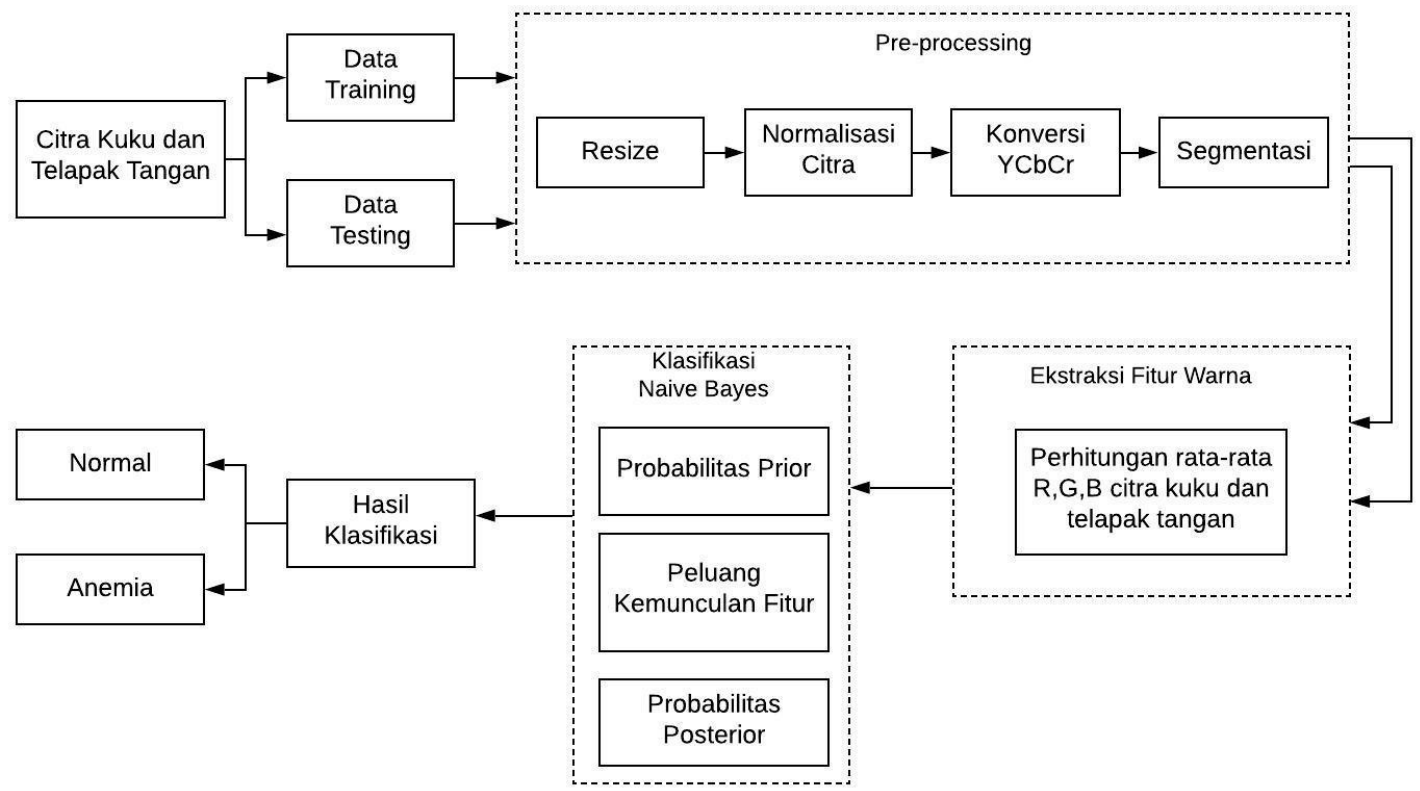

Gambar 1. Metodologi Penelitian

\subsection{Akuisisi Citra}

Akuisisi citra pada penelitian ini menggunakan kamera belakang Smartphone Samsung Galaxy A6 dengan spesifikasi kamera 16 MP. Pengambilan citra dilakukan tanpa menghidupkan lampu flash pada kamera.

\subsection{Pre-processing}

Tahapan pre-processing citra pada penelitian ini dapat dilihat pada Gambar 2.

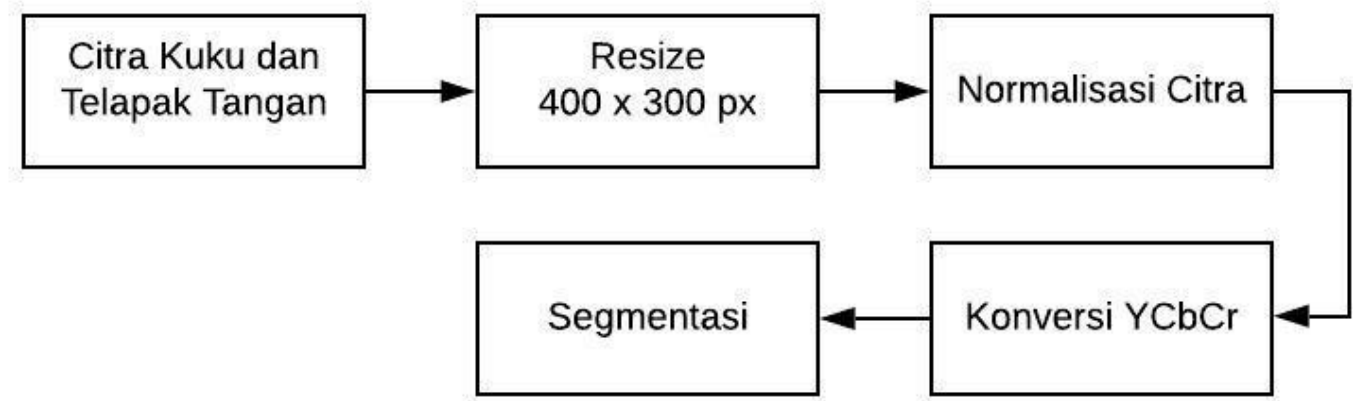

Gambar 2. Tahapan Pre-processing

\subsubsection{Penyamaan Resolusi Citra}

Citra yang telah dikumpulkan memiliki ukuran yang berbeda-beda, oleh karena itu perlu disamakan ukurannya supaya data yang masuk kedalam sistem terstandardisasi dengan baik. Pada penelitian ini ukuran citra diubah menjadi $400 \times 300$. Penyamaan ukuran citra juga berfungsi agar proses komputasi tidak memakan waktu yang lama. 


\subsubsection{Normalisasi Citra}

Normalisasi citra dilakukan untuk menghilangkan efek cahaya dan mendapatkan nilai warna konstan dari citra tersebut sebelum dikonversi ke ruang warna YCbCr. Algoritma yang digunakan untuk menormalisasi citra adalah algoritma gray world.

\subsubsection{Konversi Citra ke YCbCr}

Konversi citra ke ruang warna $\mathrm{YCbCr}$ dilakukan untuk memisahkan antara komponen cahaya dengan komponen warna dari citra. Matriks yang digunakan untuk mengonversi RGB ke YCbCr adalah sebagai berikut :

$$
\begin{gathered}
Y=16+\left(65,481 \cdot R^{\prime}+128,553 \cdot G^{\prime}+124,966 \cdot B^{\prime}\right) \\
C b=128+\left(-37,797 \cdot R^{\prime}+-74,203 \cdot G^{\prime}+112 \cdot B^{\prime}\right) \\
C r=128+\left(112 \cdot R^{\prime}+-93,786 \cdot G^{\prime}+-18,214 \cdot B^{\prime}\right)
\end{gathered}
$$

Gambar 3 merupakan citra kuku dan telapak tangan yang telah dikonversi ke ruang warna $\mathrm{YCbCr}$.

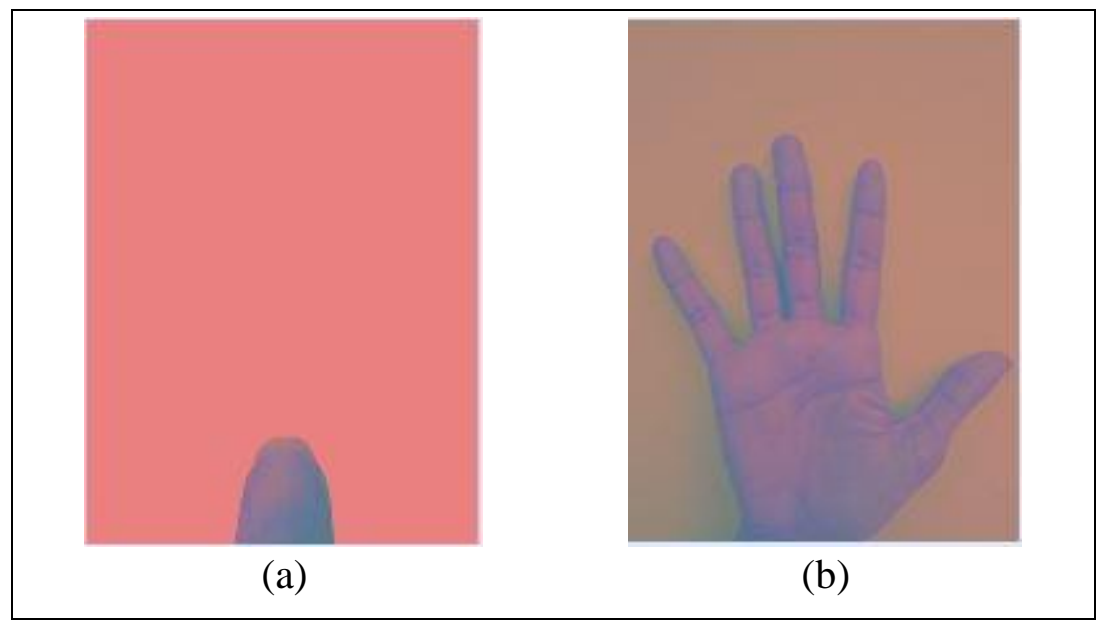

Gambar 3. Citra YCbCr (a) Citra Kuku YCbCr, (b) Citra Telapak Tangan YCbCr

\subsubsection{Segmentasi Citra}

Segmentasi citra pada penelitian ini dilakukan dengan menggunakan metode multilevel thresholding. Apabila nilai komponen warna $\mathrm{Cb}$ berada diantara 77 sampai 127 dan komponen Cr berada diantara 133 sampai 173, nilai piksel akan diubah menjadi 1. Sedangkan apabila nilai komponen $\mathrm{Cb}$ dan $\mathrm{Cr}$ berada diluar range, nilai piksel akan diubah menjadi 0. Kemudian piksel yang bernilai 1 akan dikonversi lagi ke ruang warna RGB dengan mengembalikan piksel awal. Hasilnya adalah piksel yang merupakan warna kulit akan ditampilkan, sedangkan yang bukan berwarna kulit akan ditampilkan sebagai warna hitam sehingga dihasilkan citra yang telah tersegmentasi. Citra kuku dan telapak tangan yang telah disegmentasi dapat diihat pada gambar 4. 


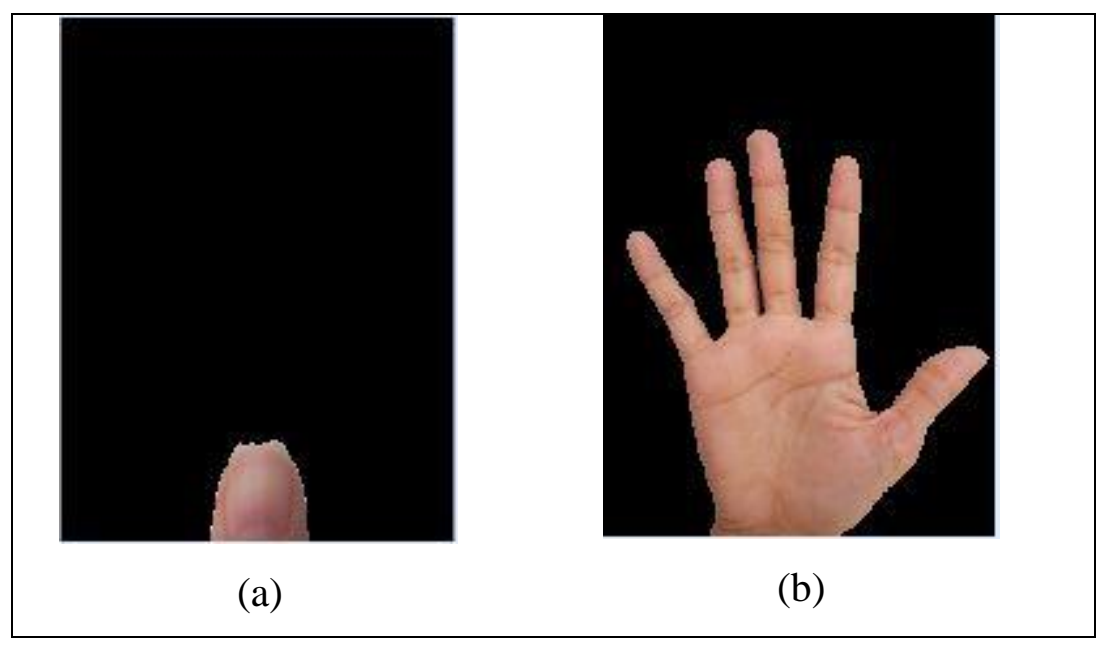

Gambar 4. Citra Segmentasi (a) Citra Segementasi Kuku, (b) Citra Segmentasi Telapak Tangan

\subsubsection{Ekstraksi Fitur Warna}

Setelah citra disegmentasi, kemudian citra tersebut akan diekstraksi fitur warnanya. Hasil dari ekstraksi fitur warna tersebut adalah nilai rata-rata RGB dari setiap citra. Kemudian nilai rata-rata RGB tersebut akan dijadikan input untuk diklasifikasi menggunakan metode naive bayes.

\subsubsection{Klasifikasi Naive Bayes}

Setelah mendapatkan nilai fitur warna, nilai-nilai tersebut digunakan sebagai masukkan untuk proses naive bayes. Dibawah ini merupakan langkah-langkah metode klasifikasi naive bayes :

1. Menghitung peluang kemunculan kelas normal dan anemia pada data latih.

2. Mencari nilai peluang kemunculan jenis kelamin dalam suatu kasus pada data latih.

3. Mencari nilai mean dan standard deviasi setiap fitur pada data latih

$$
\mu=\frac{1}{n} \sum_{i=1}^{n} x_{i}
$$

4. Mencari nilai standard deviasi setiap fitur pada data lati

$$
\sigma=\sqrt{\frac{1}{n-1} \sum_{i=1}^{n}\left(x_{i}-\mu\right)^{2}}
$$

5. Menghitung peluang kemunculan fitur

$$
P=\left(X_{i}=x_{i} \mid Y_{i}=y_{i}\right)=\frac{1}{\sqrt{2 \pi \sigma i j}} e^{-\frac{(x i-u i j)^{2}}{2 \sigma^{2} i j}}
$$

6. Mengalikan peluang kemunculan jenis kelamin dengan peluang kemunculan fitur.

7. Menjumlahkan hasil perkalian kemunculan fitur normal dan anemia untuk mendapatkan nilai evidence.

8. Menghitung probabilitas posterior dengan membagi hasil perkalian kemunculan fitur per kelas dengan nilai evidence. 


$$
\text { Posterior }=\frac{\text { Prior } \times \text { likelihood }}{\text { evidence }}
$$

9. Mencari nilai peluang tertinggi untuk mendapatkan hasil klasifikasi.

\section{Hasil dan Pembahasan}

Pada penelitian ini, pengujian sistem dilakukan dengan menguji jarak, sudut kamera, dan intensitas cahaya.

\subsection{Pengujian Jarak dan Sudut Kamera}

Pengujian jarak dan sudut kamera bertujuan untuk mendapatkan jarak dan sudut kamera yang optimal dalam mengidentifikasi objek dan kuku serta klasifikasi anemia. Pengujian ini dilakukan kepada 40 responden.

\subsubsection{Deteksi Kuku}

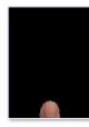

kuku 1

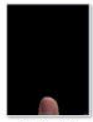

kuku 11
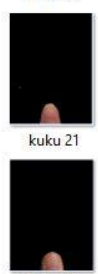

kuku 31
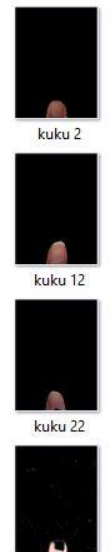

kuku 32
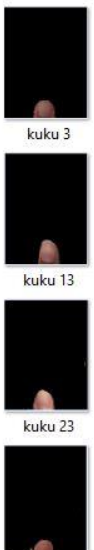

kuku 33
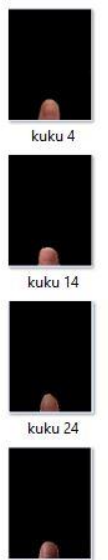

kuku 34
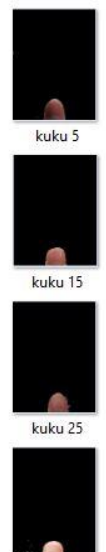

kuku 35
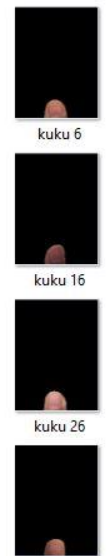

kuku 36
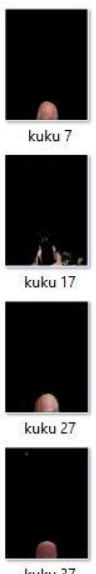

kuku 37
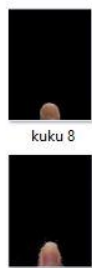

kuku 18
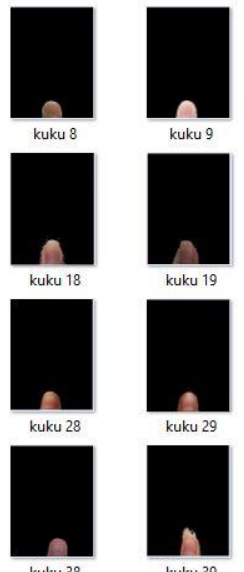

kuku 19
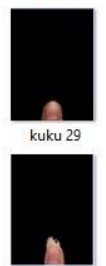

kuku 38 kuku 39
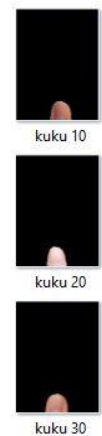

kuku 30

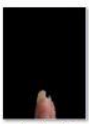

kuku 40

Gambar 5. Deteksi Kuku Jarak $10 \mathrm{~cm}$ Arah Depan

Gambar 5 merupakan hasil dari pengujian deteksi kuku dengan menggunakan jarak $10 \mathrm{~cm}$ dan citra diambil dari arah depan objek. Pada pengujian ini terdapat 2 citra yang gagal didteksi yaitu pada kuku 17 dan kuku 32.
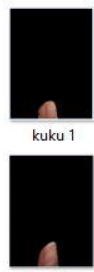

kuku 11
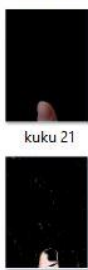

2
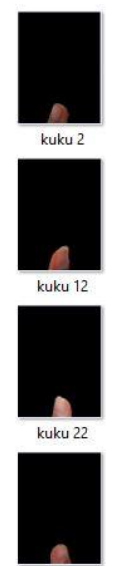

kuku 32

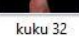

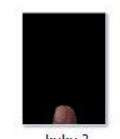

kuku 3
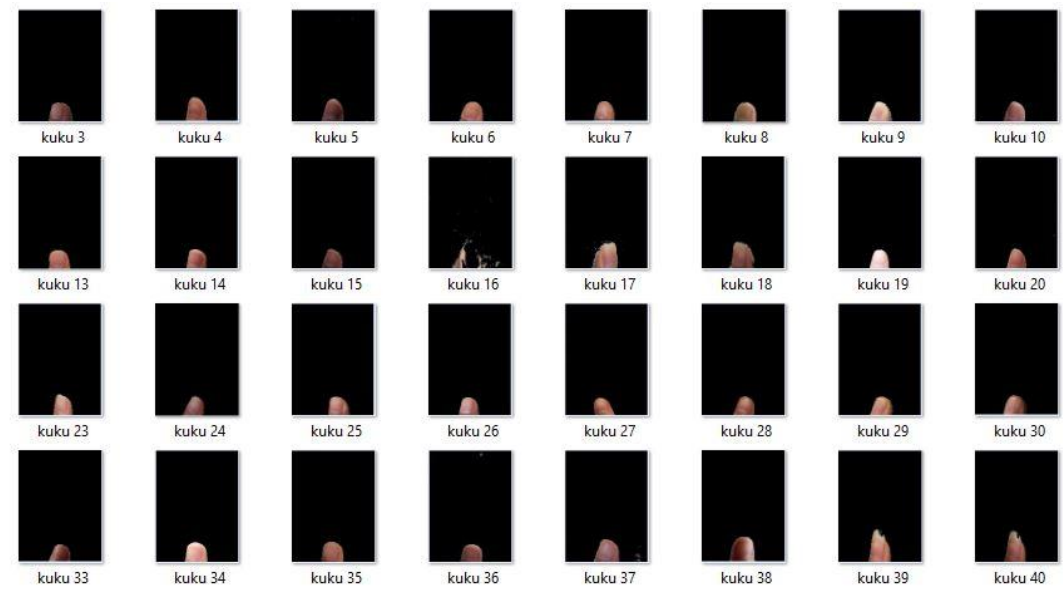

Gambar 6. Deteksi Kuku Jarak 10 cm Sudut 45 Derajat 
Gambar 6 merupakan hasil pengujian deteksi kuku dengan menggunakan jarak $10 \mathrm{~cm}$ dengan arah kamera 45 derajat. Pada pengujian ini terdapat 2 citra yang gagal dideteksi yaitu pada kuku 16 dan kuku 31.
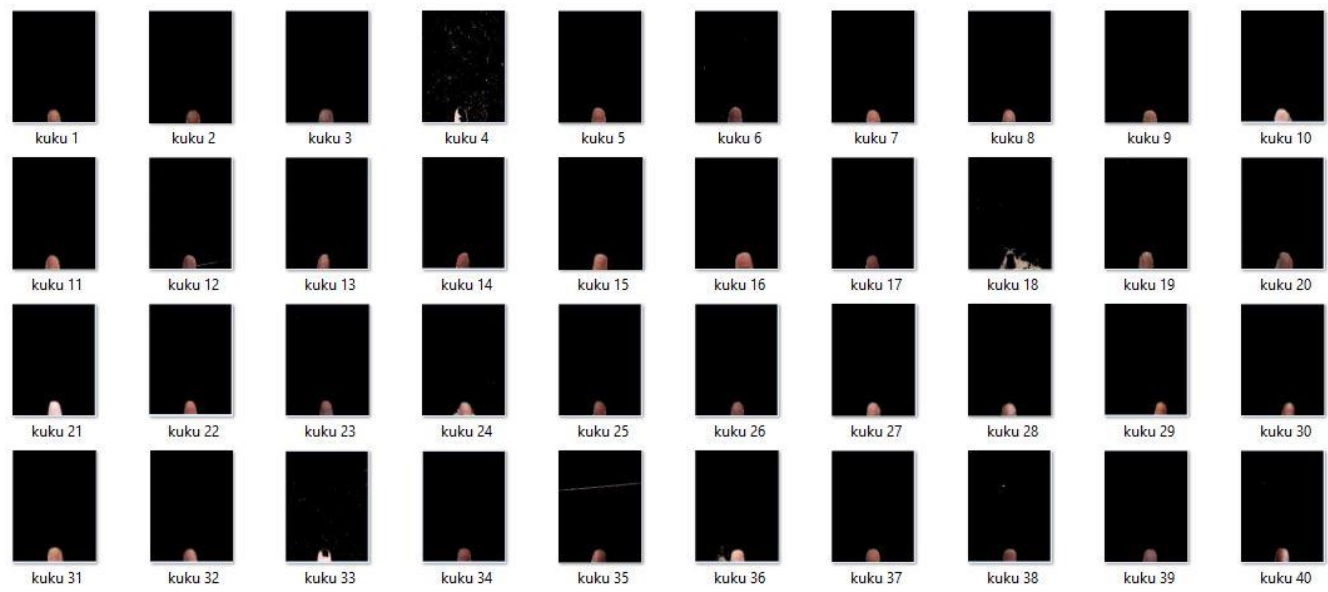

Gambar 7. Deteksi Kuku Jarak $20 \mathrm{~cm}$ Arah Depan

Gambar 7 merupakan hasil pengujian dari deteksi kuku dengan menggunakan jarak $20 \mathrm{~cm}$ dan citra diambil dari arah depan. Pada pengujian ini terdapat 3 citra yang gagal dideteksi yaitu kuku 4, kuku 18, dan kuku 33.
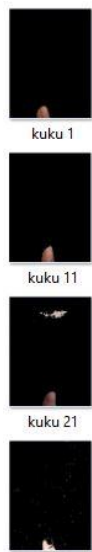

kuku 31
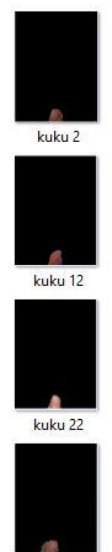

kuku 32
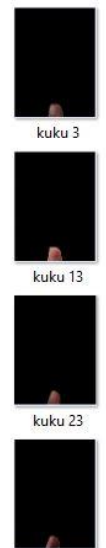

kuku 33
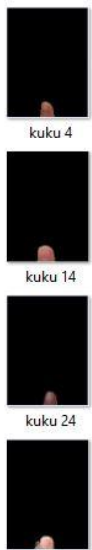

kuku 34
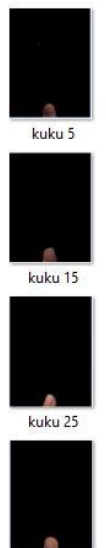

kuku 35
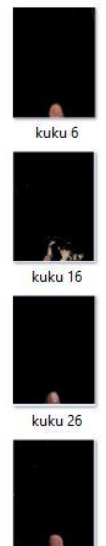

kuku 36
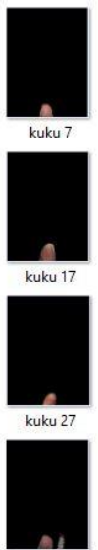

kuku 37
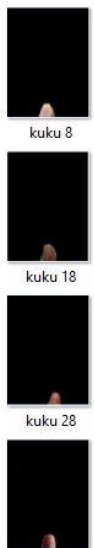

kuku 38
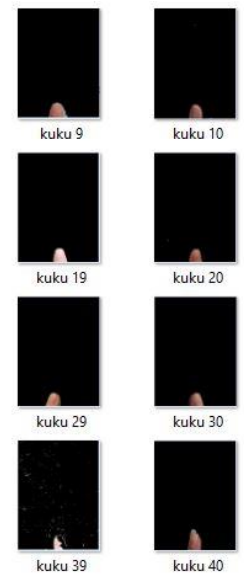

Gambar 8. Deteksi Kuku Jarak $20 \mathrm{~cm}$ Sudut 45 Derajat

Gambar 8 merupakan hasil pengujian dari deteksi kuku dengan menggunakan jarak $20 \mathrm{~cm}$ dan arah kamera 45 derajat. Pada pengujian ini terdapat 3 citra yang tidak terdeteksi yaitu kuku 16, kuku 31, dan kuku 3.

Tabel 1. Hasil Pengujian Deteksi Kuku

\begin{tabular}{|c|c|c|}
\hline Jarak & Arah & Objek Kuku Terdeteksi \\
\hline $10 \mathrm{~cm}$ & Depan & 38 \\
\hline $10 \mathrm{~cm}$ & Sudut 45 & 38 \\
\hline $20 \mathrm{~cm}$ & Depan & 37 \\
\hline $20 \mathrm{~cm}$ & Sudut 45 & 37 \\
\hline
\end{tabular}


Tabel 1 merupakan hasil dari pengujian deteksi kuku. Dari tabel 1 menunjukkan bahwa sudut pengambilan citra tidak memengaruhi performa algoritma dalam mendeteksi objek. Sedangkan jarak memiliki pengaruh terhadap performa algoritma dalam mendeteksi objek. Semakin jauh jarak antara kamera dengan objek maka semakin sering objek tidak terdeteksi. Hasil pengujian menunjukkan bahwa jarak $10 \mathrm{~cm}$ merupakan jarak optimal dalam mendeteksi kuku.

\subsubsection{Deteksi Telapak Tangan}
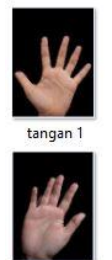

tangen 11

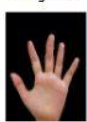

tangan 21

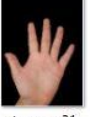

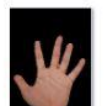
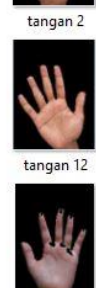

tangan 22

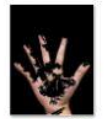

tangan 32
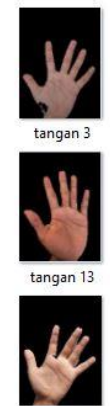

tangan 23

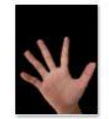

tangan 33
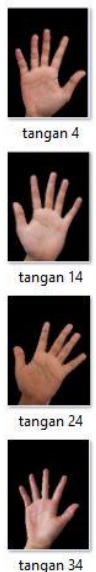
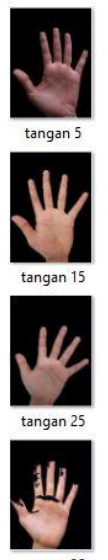

tangan 35
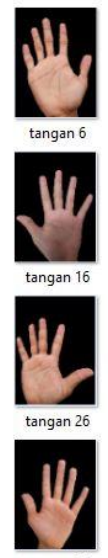

tangan 36
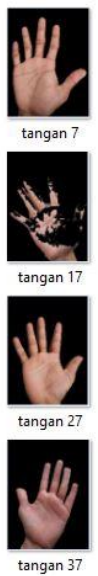
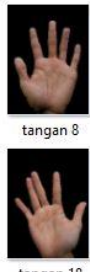

tangan
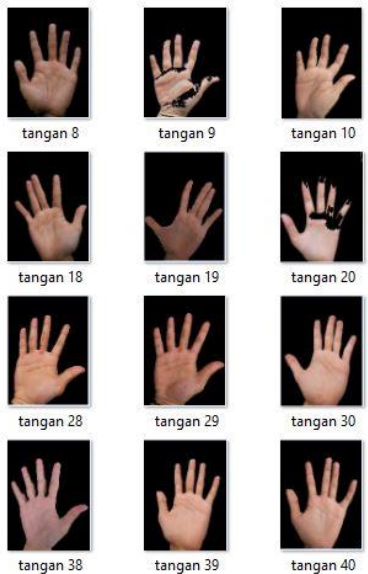

Gambar 9. Deteksi Tangan Jarak $20 \mathrm{~cm}$ Arah Depan

Gambar 9 merupakan hasil pengujian dari deteksi tangan dengan menggunakan jarak 20 $\mathrm{cm}$ dan citra diambil dari arah depan. Pada pengujian ini terdapat 2 citra yang gagal dideteksi yaitu tangan 17 dan tangan 32 .
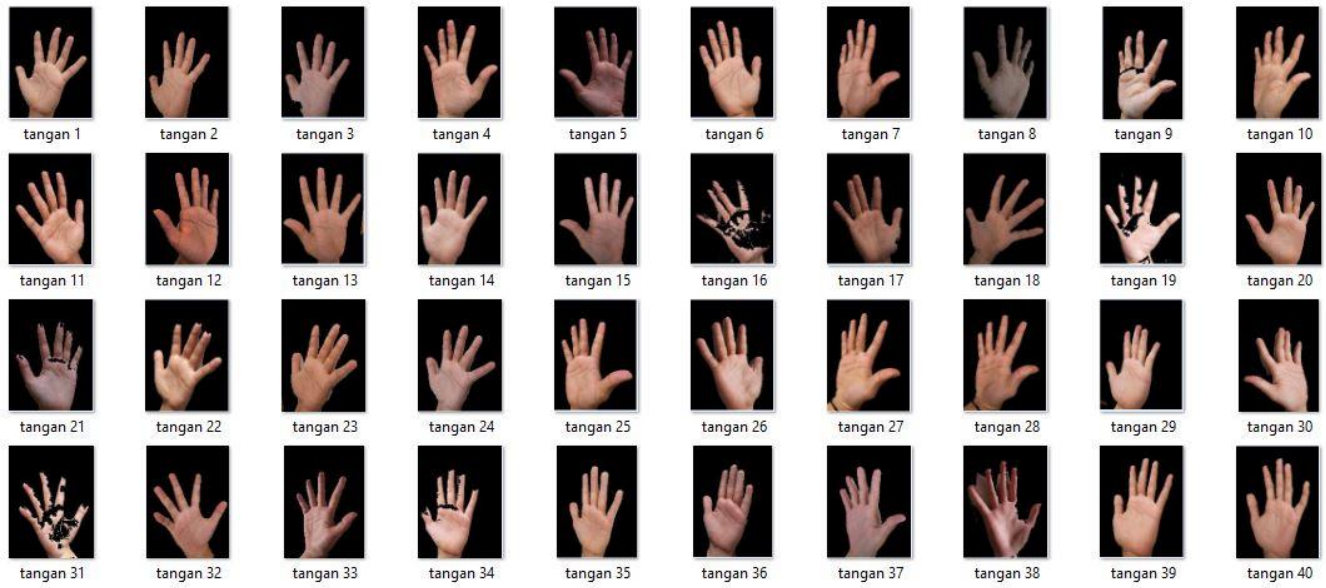

Gambar 10. Deteksi Tangan Jarak $20 \mathrm{~cm}$ Sudut 45 Derajat

Gambar 10 merupakan hasil pengujian dari deteksi telapak tangan dengan menggunakan jarak $20 \mathrm{~cm}$ dan arah kamera 45 derajat. Pada pengujian ini terdapat 2 citra yang gagal dideteksi yaitu tangan 16 dan tangan 31 . 


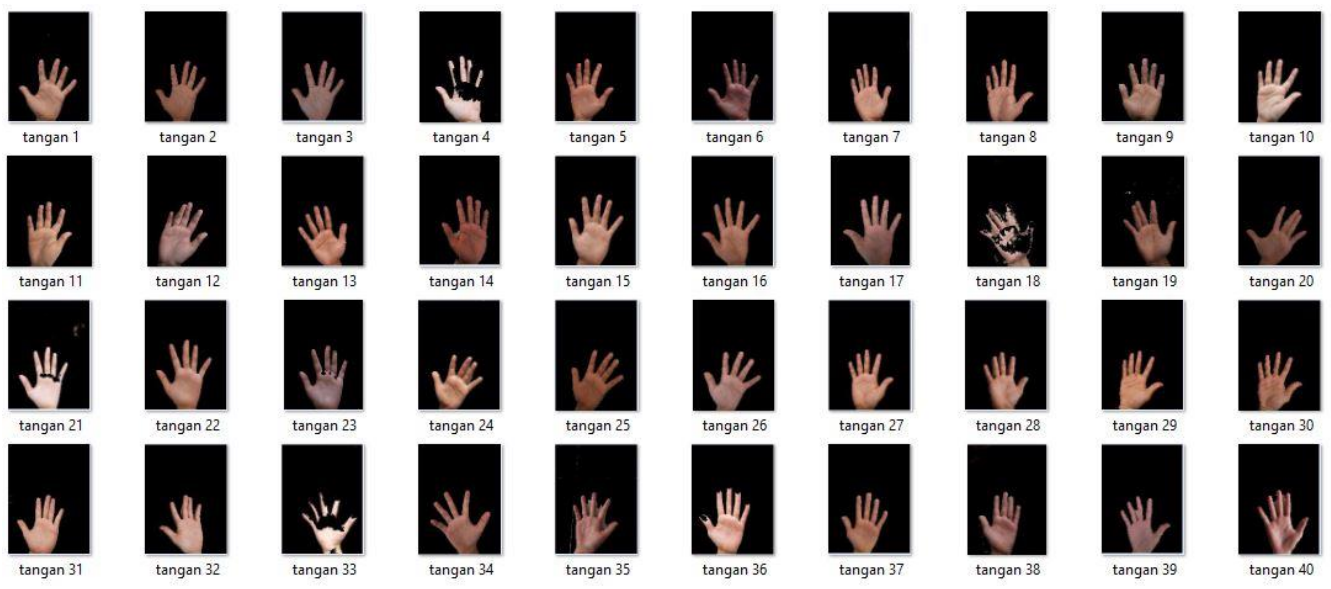

Gambar 11. Deteksi Tangan Jarak $30 \mathrm{~cm}$ Arah Depan

Gambar 11 merupakan hasil pengujian dari deteksi telapak tangan dengan menggunakan jarak $30 \mathrm{~cm}$ dan citra diambil dari arah depan. Pada pengujian ini terdapat 3 citra yang gagal dideteksi yaitu tangan 4, tangan 18, dan tangan 33 .
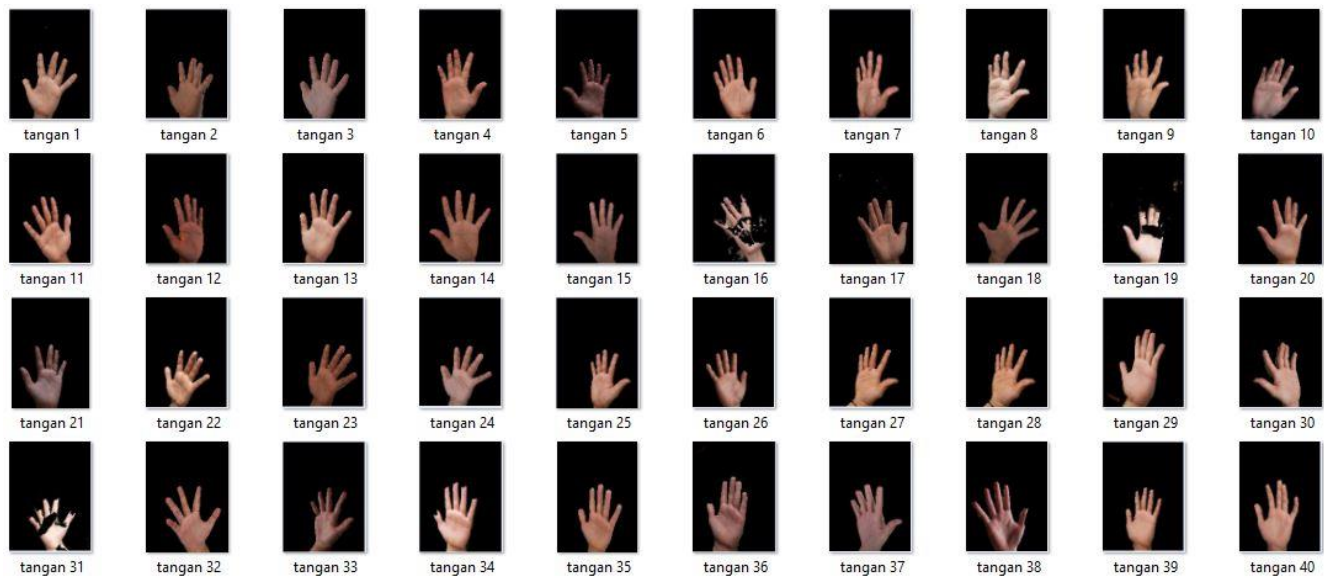

Gambar 12. Deteksi Tangan Jarak $30 \mathrm{~cm}$ Sudut 45 Derajat

Gambar 12 merupakan hasil pengujian dari deteksi telapak tangan dengan menggunakan jarak $30 \mathrm{~cm}$ dan arah 45 derajat. Pada pengujian ini terdapat 3 citra yang gagal dideteksi yaitu tangan 16, tangan 19, dan tangan 31.

Tabel 2. Hasil Pengujian Deteksi Telapak Tangan

\begin{tabular}{|c|c|c|}
\hline Jarak & Arah & Objek Telapak Tangan Terdeteksi \\
\hline $20 \mathrm{~cm}$ & Depan & 38 \\
\hline $20 \mathrm{~cm}$ & Sudut 45 & 38 \\
\hline $30 \mathrm{~cm}$ & Depan & 37 \\
\hline $30 \mathrm{~cm}$ & Sudut 45 & 37 \\
\hline
\end{tabular}

Tabel 2 merupakan hasil dari pengujian deteksi tangan. Dari tabel 2 menunjukkan bahwa sudut pengambilan citra tidak memengaruhi performa algoritma dalam mendeteksi telapak tangan. Sedangkan jarak memiliki pengaruh terhadap performa algoritma dalam mendeteksi telapak tangan. Semakin jauh jarak antara kamera dengan objek maka semakin sering telapak tangan tidak terdeteksi. 


\subsubsection{Klasifikasi Anemia}

Tabel 3. Pengujian Klasifikasi Anemia

\begin{tabular}{|c|c|c|c|c|c|}
\hline $\begin{array}{c}\text { Jarak Citra } \\
\text { Kuku }\end{array}$ & $\begin{array}{c}\text { Jarak Citra } \\
\text { Telapak Tangan }\end{array}$ & Arah & Benar & Salah & Akurasi \\
\hline $10 \mathrm{~cm}$ & $20 \mathrm{~cm}$ & Depan & 35 & 5 & $87,5 \%$ \\
\hline $10 \mathrm{~cm}$ & $20 \mathrm{~cm}$ & Sudut 45 & 29 & 11 & $72,5 \%$ \\
\hline $20 \mathrm{~cm}$ & $30 \mathrm{~cm}$ & Depan & 22 & 18 & $55 \%$ \\
\hline $20 \mathrm{~cm}$ & $30 \mathrm{~cm}$ & Sudut 45 & 19 & 21 & $47,5 \%$ \\
\hline
\end{tabular}

Berdasarkan tabel 3 jarak dan arah yang optimal dalam mengklasifikasi anemia adalah $10 \mathrm{~cm}$ untuk citra kuku dan $20 \mathrm{~cm}$ untuk citra telapak tangan, serta citra diambil dari arah depan objek. Akurasi semakin mengecil apabila jarak antara objek dengan kamera semakin jauh, dikarenakan semakin kecil objek tersebut maka sistem akan lebih sulit untuk mendeteksi warna kulit. Faktor lain yang memengaruhi kecilnya akurasi pada pengujian ini adalah karena intensitas cahaya pada data training dan data testing berbeda-beda.

\subsection{Pengujian Intensitas Cahaya}

Pengujian dengan berbagai intensitas cahaya untuk mendapatkan intensitas cahaya yang optimal dalam melakukan klasifikasi. Pada pengujian ini digunakan jarak dan arah optimal dari pengujian sebelumnya yaitu jarak $10 \mathrm{~cm}$ untuk citra kuku dan $20 \mathrm{~cm}$ untuk citra telapak tangan, serta citra diambil dari arah depan objek. Pengujian dilakukan kepada 13 responden dengan 3 intensitas cahaya yang berbeda.

Tabel 4. Pengujian Pencahayaan

\begin{tabular}{|c|c|c|c|}
\hline Cahaya (Lux) & Benar & Salah & Akurasi \\
\hline 24 Lux & 9 & 4 & $69,2 \%$ \\
\hline 5362 Lux & 12 & 1 & $92,3 \%$ \\
\hline 9856 Lux & 11 & 2 & $84,6 \%$ \\
\hline
\end{tabular}

Berdasarkan tabel 4, intensitas cahaya yang paling optimal dalam mengklasifikasi anemia adalah 5362 lux. Pada intensitas tersebut, sistem mampu mencapai akurasi 92,3\% dengan kesalahan 1 kali klasifikasi. Tingginya tingkat akurasi pada intensitas cahaya 5362 lux dikarenakan pada intensitas tersebut objek dapat menunjukkan warna aslinya pada citra. Sedangkan apabila pada intensitas 9856 lux, nilai intensitas RGB menjadi lebih terang dari nilai aslinya dan objek seringkali terkena pantulan cahaya matahari yang mengakibatkan objek gagal terdeteksi. Sebaliknya, pada intensitas 24 lux yang diambil di dalam ruangan dengan menggunakan cahaya lampu, setiap objek cenderung lebih gelap.

\section{Kesimpulan dan Saran}

Berdasarkan penelitian yang telah dilakukan, dapat disimpulkan bahwa metode naive bayes dapat mengklasifikasi anemia dengan cara mencari peluang kemunculan nilai rata-rata RGB kuku dan telapak tangan berdasarkan nilai data latih yang sudah disimpan didalam database. Akurasi yang dihasilkan oleh penelitian ini sebesar 87,5\% dengan intensitas cahaya yang berbeda-beda, dan tingkat akurasi sebesar 92,3\% dengan intensitas cahaya 5362 Lux dengan menggunakan jarak $10 \mathrm{~cm}$ untuk kuku dan $20 \mathrm{~cm}$ untuk telapak tangan.

Pada penelitian ini masih terdapat beberapa kekurangan yang diharapkan dapat dikembangkan untuk penelitian selanjutnya. Beberapa hal yang dapat dilakukan untuk pengembangan penelitian ini adalah menambahkan tahap pre-processing citra untuk menormalisasikan cahaya karena pada penelitian ini belum dapat menormalisasikan citra pada pencahayaan yang berbeda-beda sehingga pengambilan dataset pada pencahayaan yang 
berbeda-beda akan membuat akurasi menjadi rendah. Kemudian hal yang dapat dikembangkan adalah penambahan metode deteksi tepi untuk segmentasi kuku. Pada penelitian ini segmentasi kuku masih dilakukan berdasarkan warna, sehingga kulit yang berada disekitar kuku tidak tersegmentasi.

\section{Daftar Pustaka}

[1] Masrizal, “Anemia defisiensi besi,” J. Kesehat. Masyarakay, vol. 2, no. 1, pp. 140-145, 2007.

[2] J. R. Zucker, B. A. Perkins, H. Jafari, J. Otieno, C. Obonyo, and C. C. Campbell, "Clinical signs for the recognition of children with moderate or severe anaemia in western Kenya," Buketin World Heal. Organ., vol. 75, no. Supplement 1, pp. 97-102, 1997.

[3] Y. Usman, "Validasi Klasifikasi Anemia Pada Balita Dengan Melihat Kepucatan Telapak Tangan,” Media Litbang Kesehat., vol. 13, no. 1, pp. 14-19, 2003.

[4] S. Lee, C. Yang, T.-W. Hou, and C.-H. Yeh, "An Image Preprocessing Method for Fingernail Segmentation in Microscopy Image," 2017 IEEE 2nd Int. Conf. Signal Image Process. An, pp. 489-493, 2017.

[5] I. Usuman, A. Dharmawan, A. Zatu, and K. Frisky, "Sistem Pendeteksi Kulit Manusia Menggunakan Segmentasi Warna Kulit Pada Tipe Citra HSV ( Hue Saturation Value )," IJEIS, vol. 2, no. 2, pp. 143-154, 2012.

[6] J. Waykule and A. Katre, "Skin Segmentation Using YCBCR and RGB Color Models," Int. J. Adv. Res. Comput. Sience Softw. Eng., vol. 4, no. 7, pp. 341-346, 2016.

[7] R. Wijanarko and N. Eko, "Deteksi Wajah Berbasis Segmentasi Warna Kulit Menggunakan Ruang Warna YCbCr dan Template MAtching," J. Ilm. Cendekia Ekskata, pp. 1-6, 2017.

[8] K. Basha, P. Ganesan, V. Kalist, B. S. Sathish, and J. M. Mary, "Comparative Study of Skin Color Detection and Segmentation in HSV and YCbCr Color Space," 3rd Int. Conf. Recent Trends Comput. 2015, vol. 57, pp. 41-48, 2015.

[9] A. Tamir, C. S. Jahan, M. S. Saif, S. U. Zaman, M. Islam, and A. Intisar, "Detection of Anemia from Image of the Anterior Conjunctiva of the Eye by Image Processing and Thresholding," 2017 IEEE Reg. 10 Humanit. Technol. Conf., vol. 17, pp. 697-701, 2017.

[10] R. G. Mannino et al., "Smartphone app for non-invasive detection of anemia using only patient-sourced photos," Nat. Commun., pp. 2-11, 2018.

[11] N. Sevani, Fredicia, and G. B. V Persulessy, "Detection anemia based on conjunctiva pallor level using k-means a lgorithm," 2nd Nommensen Int. Conf. Technol. Eng., vol. 420, pp. 1-8, 2018.

[12] S. Dhanasekaran and N. R. Shanker, "Detection of Anemia Disease Using PSO Algorithm and LBP Texture Analysis," Int. J. Pure Appl. Math., vol. 120, no. 6, pp. 1526, 2018. 
[13] V. R. Balaji, S. T. Suganthi, R. Rajadevi, V. K. Kumar, B. S. Balaji, and S. Pandiyan, "Skin disease detection and segmentation using dynamic graph cut algorithm and classification through Naive Bayes classifier," Measurement, vol. 163, no. 107922, pp. $1-14,2020$.

[14] A.-W. Hosne, T. Sadia, A. Tahsin, T. Asad, and N. Tasnim, "Palm Print Recognition System using Naive Bayes Classifier and Image Palm Print Recognition System using Naive Bayes Classifier and Image Processing Tools," Commun. Appl. Electron., vol. 2, no. 6, pp. 45-49, 2018.

[15] H. Septiana, K. Aji, and C. A. Sari, "Classification of Skin Diseases Types using Naive Bayes Classifier based on Local Binary Pattern Features," 2020 Int. Semin. Appl. Technol. Inf. Commun., vol. 20, pp. 61-66, 2020.

[16] D. Kurniawan, R. Maulana, M. Hannats, and H. Ichsan, "Implementasi Pendeteksi Penyakit Paru-Paru Berdasarkan Warna Kuku dan Suhu Tubuh Berbasis Sensor TCS3200 Dan Sensor LM35 dengan Metode Naive Bayes," J. Pengemb. Teknol. Inf. dan Ilmu Komput., vol. 3, no. 4, pp. 3383-3389, 2019.

[17] D. Rossiawan et al., "Identifikasi Wajah Berbasis Segmentasi Warna Kulit Wajah Menggunakan Naive Bayes Classifier,” J. Teknol. Inf., vol. 9, no. 2, pp. 99-106, 2018.

[18] T. Ashfaq and K. Khurshid, "Classification of Hand Gestures Using Gabor Filter with Bayesian and Naïve Bayes Classifier," Int. J. Adv. Comput. Sci. Appl., vol. 7, no. 3, pp. 276-279, 2016. 